\title{
Industrial Heritage, Regeneration of Cities and Public Policies in the 1990s: Elements of a French/British Comparison
}

\author{
Michel Rautenberg* \\ Université de Lyon, CNRS-UMR 5283 Centre Max Weber, Saint-Etienne, France
}

\begin{abstract}
In West-European countries, public policies often argue that heritage-and in particular industrial heritage-could be an effective resource for economic and social development in areas which have been severely affected by de-industrialisation. During the 1990s, the French and British governments proposed two different strategies on the role that industrial heritage might have in repairing the effects of deindustrialisation. From a global point of view, the British promoted tourism while the French preferred cultural projects. However, concrete examples show a more complex situation. First, already at that time local authorities and local powers plaid an important role especially in Great-Britain- in the politics of heritage. Secondly, these politics are impacted by struggles and tension between local populations and institutions or policies considered as 'external' to the territory or the community. Thirdly, the local population see these projects as being based on a 'mythification' of labour and of the workers' culture. Finally, whatever the method, they appear as being imposed and were accepted with difficulty by the population and by the local governments.
\end{abstract}

Keywords: Industrial Heritage; Public Policies; Urban Regeneration; Wales; NordPas-de-Calais

\section{Introduction}

In West-European countries the extended application of the category of heritage to new objects, such as industrial vestiges or expressions of collective memory, has been among the most important cultural phenomenon of the last three decades of the twentieth century. It can be seen as one expression of the rise of a 'contemporary regime of historicity' (Koselleck 1990) that has emerged in the West. According to Koselleck, today there is a tension between our collective experience and expectations; faith in Progress is fading and the past takes a weaker place in our collective representation of time. Consequently, as Hartog (2005, p.15) states, we would be entirely engaged in the present, an 'omnipresent present that has no horizon other than itself'. Heritage has become one way of experiencing ruptures with the past and reducing them. Another factor of this contemporary regime of historicity is that heritage is also largely called on when describing and preserving the diversity of culture, to promote local empowerment and sustainable development (Hartog 2005).

This general context of an ever-increasing presence of heritage in our present has driven several French historians, sociologists and other 'intellectuals' to denounce 'abuses' of heritage and its 'ardent obligation' (Debray 1999). For most of them, the main actor - if not the actor responsible for this, would be the French Ministry of Culture, particularly its Heritage Division where 'everything related to heritage is discussed' (Hartog 2005, p.10). Another position, more popular in Great Britain than in France, insists on social dynamics and their relationships, sometimes conflicting, with institutions. As Harvey (2008, p.19) notes, 'The history of heritage is also a history of the struggle to control the use of heritage within society'. This approach belongs to a line of English studies on heritage which appeared during the nineties, rooted in the Cultural Studies conception of the place of popular cultures in the 


\section{Rautenberg}

struggle against the 'cultural hegemony' — as Gramsci said — of the bourgeoisie. Criticizing the academic conceptions of heritage, Raphael Samuel (1994) stresses that 'heritage mania' is a symptom of the blurring of the high/low culture opposition; heritage becomes appropriated by everyone despite the attempts of the upper class. It seems that Samuel's work has had some influence on the modern conception of heritage in the U.K. Referring to Samuel's work, Dicks (2000, p.63) argues that it was far from being 'Tatcherism in period dress', because 'heritage is harnessed by different political interests at different times' (id). Alongside Bella Dicks, other researchers have been influenced by Samuel's work, stressing that the heritage of the working class cannot be taken into account in a broad historical framework, since its function would be above all to stand as 'a theatre of memory' (Smith, Shackel and Campbell, 2011). Although almost unknown in France, even when closely related positions have been defended by some sociologists and anthropologists (Fabre 2000, Glévarec and Saez 2002, Rautenberg 2003, Tornatore 2010), Raphael's work raises an interesting point when he analyses the process of heritage-making not only as a process imposed by public policies, but above all as a tension between institutions - especially national institutions - and the civil society. The heritage-making process is more complex that what top-down or bottom-up analyses can explain. Public institutions are involved in 'heritagization', at several levels and civil society cannot be artificially identified with policy and administrations, as local communities and different sorts of associations are closely involved in the process. According to the French say, the history of heritage is not a 'long quiet river'.

In a recent book, Lucie K. Morisset (2009) proposes an alternative analysis of the French historical heritage studies as personified by Pierre Nora. Following the French historian of architecture Françoise Choay, she defends the notion that 'the idea and object of patrimony are specific to the time and place they belong to' (2010, p.55). She argues that, unlike history, heritage - she prefers the word patrimony ${ }^{2}-$ links our present not only to time but also to our material environment, which objectifies our identity feelings by putting them in physical places, and to other people or social groups that form our territory. Studying the history of Quebec's 'patrimoine' (heritage), she shows that several 'regimes of authenticity' have succeeded since 1922, the date of the first Act Respecting the Preservation of Monuments and objects of Art having a Historic or Artistic Interest. Heritage is supposed to tell us something about ourselves: Who are we? Where do we come from? However, each period of the past has built its own interpretation of authenticity, and patrimonial objects, like fossils, accumulate meanings that can emerge from the collective memory or archives. These 'regimes of authenticity' originate in seeing the patrimonial object 'as a container or vehicle of patrimonial investiture' which 'proceeds as tied to the life of the patrimonial object (...) according to a process of accumulation and fossilization' (Reference is missing). Finally, we must consider, with Morisset, the patrimonial object as 'the expression of a balance (...) between relationships with Time, Space and the Others' (2010, p.56). By applying Fredrik Barth's (1969) analysis of the relationship of ethnic groups' identity to heritage, we could say that for Lucie K Morisset, heritage would be a modern word to designate the common signs and emblems that we need when negotiating our collective identity in our immediate environment. Those signs and emblems are socially interpreted in various 'regimes of authenticity' that mingle with each other.

This is the conception of heritage that we shall consider in the following pages. Then, we argue that several regimes of heritage coexist in western countries, according to the place of national politics, involvement of local government and civil society. Among several territorial contexts, middle size cities and urban areas have developed specific characteristics that we have to consider. Specific regimes of heritage have to be taken in account; particularly since the 1990s, when urban regeneration has been extended to all West-European countries. How 
was this regime of heritage applied? Who was concerned, and how? What was the impact of national policies?

During the 1980s and 1990s, heritage has strongly impacted in the UK under the new regime of governance imposed by the conservative government (Dicks 2000). In France, despite the liberalisation of the economy, heritage (patrimony) policies changed slowly and the academic conception was dominant until the early 2000s. We could caricature a French-British comparison by saying that in Great Britain heritage had to be married with marketization, and in France, it had to favour 'cultural development', national or local. Two examples, one from the UK the other from France, will help us to study this opposition between economy and culture. The first example is the Rhondda Heritage Park project, an old Victorian colliery in south Wales studied by the sociologist Bella Dicks (2000). Before becoming 'a small, local, loss-making and publicly-founded heritage museum', as said Dicks (2003, p.31), during the 1980s it appeared to be the commercial venture par excellence for the Welsh Development Agency, considered to be 'the arm of the Conservative-controlled UK Government' before devolution (Dicks 2003, p.31). The second example is a cultural centre called Culture Commune ('Common Culture') created at Loos-en-Gohelle, in the French Bassin minier du Nord-Pas-de-Calais, in the early 1990s. The original project was to produce and promote artistic creations based on local memories. Prior to a serious financial crisis that weakened the foundation managing the project, at the beginning of the 2000s, the Culture Commune was one of the leaders of the European movement Banlieues d'Europe. The authors carried out fieldwork there in 2006 and 2007 (Rautenberg and Trigano 2010) ${ }^{3}$. We shall see that despite apparently very different public policies, the similarities are significant. Before presenting these two cases, it will necessary to spend a few words on urban policies.

\section{Industrial Heritage in the Realm of Politics}

French historians often insist that the politics of heritage and memory have been developed by the State in order to keep its hold on the territory (Nora 1986). During the last decades of the twentieth century, French and British governments, both right- and left-wing, promoted heritage as a remedy to address the crisis of Keynesian capitalism (Harvey 1985). The industrial disease left a large quantity of scars in several regions disputed by local and national authorities. Among several types of responses, in several cities 'industrial ruins' (Edensor 2005) became alternative places for new aesthetic, unofficial art and social invention, with or without the consent of the local authorities. Former factories were transformed into artists' lofts, perhaps because 'Ruins offer an aesthetic experience that bypasses the normal designs of the city, often over-regulated, boring and too smooth' (Edensor 2005b). Unexpectedly, the denominations of industrial activities are often reinvented by artists when they name their workplace or explain their jobs, and workers' memories are often revisited in artistic events. According to Chaudoir (2009, p.60), they appear as being closer to the raw reality of the factory, to production, rather than to the abstraction of creation. We could say that the vestiges of the industrial period are recycled in a new artistic and cultural reality.

We should not be surprised by this use of the industrial past. Michael Peter Smith and Thomas Bender (2001) insist on the fact that Modernity is not a global and undifferentiated phenomenon. Modernity is located, often in harmony with a local expression of the past and heritage. They give several examples of the wide variety of such propositions, from the invention of a traditional marketplace in Mexico to the reverence for antiquity in modern China. As they note, 'Tradition, in varying degrees inherited and invented, plays a crucial role in the path to modernity outside of the zone of the metropole' $(2001$, p.3). Not only was heritage defined as important to the development of tourism, but history also had important ideological functions. On one hand, history makes it possible to impose a political and urban 


\section{Rautenberg}

order; on the other hand, it offers arguments for resisting the destruction of a building or part of a city. Context, they write, is 'thick enough, contradictory enough, to allow or permit (...) more than one path of social action' (Smith and Bender 2001, p.6). We have to be aware of the importance of locality and to be suspicious of too general discourses about the effects of modernity: modernity can go hand in hand with the reinvention of diversity. According to this conception of the regeneration of cities, we can add that the context of a city is more or less widely shaped by the past. So, heritage can be understood as a set of features of the past, which is a compromise between different sorts of social, economic and political actors.

Urban policies were brought to the forefront in the 1990s. In most European countries, states began to delegate the implementation of development policies to the urban elites (Béhar and Estèbe 2009). The consequences were the growing importance of heritage in urban regeneration policies and new consideration for ancient districts, for the former topography and for the facades of buildings. Professionals, local elites and local governments saw urban and industrial heritage as instruments of urban regeneration because they were supposed to support the specific identity of the place. This became one of the main slogans of urban competition (Pinson 2009). Even in France, the state is no longer the main actor in these policies and, more or less joined by state policies, cities are becoming the main actors in the building of urban heritage. The development of urban tourism, the creation by UNESCO of the Organization of World Heritage Cities, the attraction of the 'new urban class' to the ancient city centres and many others developments are signs that heritage policies can no longer be understood without taking into account cities' public policies.

Developing this idea, Patrick Le Galès and Pierre Lascoume (2005) explain that this new paradigm of urban policy must be linked to a more general evolution of governance in Europe, considering governance as all the rules, networks, public institutions, collective practices, etc. which allow the management of society. With European integration, the framework of relationships between cities and states has changed. It no longer obeys the asymmetric model, whereby the centre more or less succeeds in imposing its decisions on the peripheries; we witness a more polycentric model engendered by new partnerships with the European Union and European cities networks. The State is no longer so central, because of the multiplicity of new social, economic and institutional actors. Patrick Le Galès (2003) underlines an important paradox. Our modernity goes with new forms of individualism; with the increase in mobility, we are more autonomous than ever, and we appear to have fewer functional links with the territory where we live. However, because more often than in the past we choose the place where we live, we are more interested in such a place; the 'territory becomes a central element of our individual experience' (ibid, p. 200). Thus, some territories have succeeded in becoming attractive, while others have lost this quality. In the cases we are interested in, an important challenge is to develop, in the new political context that we have outlined, a local policy capable of transforming industrial ruins and vestiges into positive visions of pleasant places. A new map of cities good to live in is being drawn up. In this map, culture and heritage have an important place, and the opportunity to play a role in urban planning. Culture can support economic development and competition between cities. It is called upon in order to defend local identity, as seen above, or to facilitate governance and the relationships between local government and the population.

Finally, Le Galès insists that cities have not disappeared in globalisation, especially the medium-sized ones. He denounces the popular idea of the 'end of the cities'. The European nation-states and the EU help cities to develop because they are necessary in urban planning, as places where social and cultural links can be expressed. Among the different situations in different national contexts, Patrick Le Galès points out two models that seem to emerge. One is the British model, originating in specific cities in British history as they emerged from the industrial revolution; a model deeply impacted by the neo-liberal Thatcher's reforms, which 
encouraged partnerships between the public and the private. The other is a continental model in which for a very long time relations between states and cities have been an important element of urban development (Le Galès 2003, p.390).

The two situations that we shall now analyse are urban areas deeply marked by a coal-mining culture with strong work identities, a memory of social struggles, a strong opposition to capitalism, weak local government and a significant role played by companies in territorial management. In these two areas, in the 1980s and 1990s culture and heritage preservation appeared as solutions for new development. At first sight, they are not middle-sized cities such as those described by Le Galès. However, we shall observe similar processes towards new governance and new functions for the remains of their industrial past. We shall see that in both situations, heritage has been stereotyped and mythicized in order to be used for public policies and contribute to building new collective identities. As we have shown, opposing French and British models certainly facilitate our analysis, but should be used with care.

\section{Coal-Mining in the North of France}

Mining began at the end of the eighteenth century. The Northern region became the biggest coal-mining area in France from the mid nineteenth century until mining ended in 1990 at Oignies, a village located 20 kilometres to the south of Lille. The 'bassin minier' as it is now called, the 'black land' as it was called before, is 120 kilometres long and between 4 and 10 kilometres wide. In 1947, just after nationalisation, there were more than 200,000 workers including 135,000 underground miners; only 3,307 coal-workers remained in 1990 (Rabier 2002). From the 1920s onwards, more and more miners came from abroad: in 1927, over 80,000 came from Poland, where the majority did not return after the war. These became very organized communities, with their own churches, their own primary teachers, shops and cultural centres (Ponty 1995). In spite of the official French model of integration, they were allowed to keep or even set up special institutions to develop specific cultural, national and religious attachments. Their place was so relevant in the 'black land' that they influenced a large number of cultural practices, such as music bands and cuisine.

From the 1950s onwards, national companies hired people from Morocco and Algeria on short-term contracts in order to prevent them from gaining the advantages of the miners' status. However, most of them succeeded in staying and made up the majority of underground miners in the 1960s and 1970s (Cegarra 1999). They were victims of ostracism, despite the well-known adage: 'underground, everybody is black'. Nevertheless, they were largely 'invisible' in the collective memory at the beginning of the $2000 \mathrm{~s}$, when we began our investigations. For example, at the very popular Lewarde museum, 40 kilometres from Loosen-Gohelle, many guides originated from Polish families and spoke of their 'experiences' as underground miners even when they had only spent a very short time underground. The first exhibition in Lewarde and publication about North-African coal-miners took place only in $2004^{4}$.

Nowadays, landscapes and local society are still steeped in mining activities. They continue to express the 'mining arrangement' (Rabier 2002) through urbanism, industrial ruins and slag heaps, as well as through social relationships that continue to be based on an obsolete paternalism, now by local politicians instead of the engineers of the colliery. As in Wales, miners are considered heroes of the industrial epic. However, their place in the national imagination seems to differ from the British case, for the French national imagination is more attached to the campaign and to the 'valeurs de la République', than to its industrial past.

In the 'black land' the economic depression was and continues to be particularly severe. It is an economic social and cultural depression, most indicators of social and cultural development being well below the regional average thus making this one of the poorest regions in France (Rabier 2002). Here, fewer pupils passed the baccalauréat, and there were 


\section{Rautenberg}

fewer cultural facilities, fewer state schools, and very few libraries. Moreover, a large proportion of local people were literally encysted in their district (ibid). With the exception of the two major cities of Lens and Béthune, the sole cultural policies were aimed at supporting the local orchestras (the 'harmonies municipales') and to preserve the memory of the mining activity in small museums and associations.

In line with typical French policy, in the 1980s and 1990s (Poirrier 2010), one way to support social and economic development has been to invest in culture. The 'Houillères', the national coal-mining firm, set up the coal-mining museum in Lewarde, on the edge of the region. To date, the ministry of Culture has protected several buildings and civil architecture that testify to the coal-mining activities 5 . For example, the building where the Culture Commune was established in 1989, the 11/19, became a listed building in 1992. The founder and director, Chantal Lamare, persuaded some members of the local civil society and of the local governments that raising the cultural level was a condition to addressing social and economic depression; she also persuaded them that drawing on local history and collective memory was the best way to help people to accept contemporary expressions of art (Rautenberg and Trigano 2009). A few simple ideas guided the Culture Commune project. First, there was the idea to have a place in which to create cultural events, which would be presented in the 34 municipalities taking part in the project. Another key idea was to mix artistic disciplines in order to encourage new forms of creation, and to mix artists with the public. Finally, the Commune was a way to preserve the 'strength of the places' and the history of the population in the artistic choices.

'Work' was the most important word behind such artistic and cultural activity. The place where actors prepare their performances is called 'la Fabrique' (the factory); 'work' was a constant value linking the present to the past, which gave meaning to heritage and brought together industrial labour and cultural creation. Several theatrical performances focused on the miners' uprisings, their living conditions and the power of companies over their everyday lives. When one of the authors - a miner's son - was questioned about his work, he explained that his aim was to show miners' at work, not only to express their pain and alienation but above all their resistance: as for the actor, the body is the miner's main tool (Trigano 2010). Their body was often the only instrument available to miners in rebelling against their proletarian condition, to escape from their daily life by cycling or by exercising social solidarity by doing odd jobs in the neighbourhood. Most of the artistic performances, theatre, music and poetry produced or presented by the Culture Commune in the 34 municipalities militate in favour of social legitimacy and for the still-living workers' culture.

The philosophical choice was to give social legitimacy to the workers' culture, whatever their ethnic origins and gender. The productions were aimed at a large public, but also sometimes at a very local one. For example, a producer directed a play with Algerian and Moroccan miners' wives, which was based on an ethnographic collection of their memories. Only families and a happy few others were invited to the performance. The purpose was not to stage a popular artistic performance, but to make those families proud of their life and past.

However, the economic and political situation of the association was difficult up to the time of our enquiries. Most of the plays and concerts were popular and $64 \%$ of the public came from the surrounding municipalities, but most of the audience did not pay or were schoolchildren $^{6}$. We met few miners and workers among the public attending the performances; a qualitative assessment showed that the public belonged mainly to the lowermiddle class (social workers, teachers). In 2006, the ministry of culture decided that they would no longer recognize the centre, considering it too 'local' and its artistic programme not ambitious enough (Rautenberg and Trigano 2009). In fact, there were two conflicting conceptions of heritage and culture. For the Culture Commune, heritage was above all about 
the experience of the people who lived on a territory; for the Ministry of Culture heritage originated above all in values and symbols that had to be shared by the whole nation.

\section{The Rhondda Heritage Park}

The project of the Rhondda Heritage Park in the UK concerned an old Victorian colliery that ceased production in 1983. The peak of coal production was between the two world wars. Between 1978 and 1987, 90,000 jobs were lost, and 23 collieries closed between 1980 and 1988 (Dicks 2000). In the same period, under Margaret Thatcher's government, economic policy and urban regeneration became directed towards the private sector via governmental agencies. In the 1980s, several public-funded programmes were set up in South Wales when it was granted the Objective 2 programme by the European Commission. As Dicks reports, 'This package was designed to foster an entrepreneurial approach to economic development on the part of local agencies of governance' (2000, p.11).

Two possibilities were offered to the Rhondda Valley residents: 're-greening' the Valley or preserving its industrial identity. The choice of preserving the industrial heritage was made partly because of the local decision to regenerate gradually the local identity, partly because of the challenge that industrial tourism represented in terms of economic development (Dicks 2003). The initial impetus for the heritage museum came from a local, grass-roots initiative by ex-miners and mining history enthusiasts to save the Lewis Merthyr colliery from demolition (ibid). However, as its potential to become a resource for much-needed economic regeneration was recognised by the Welsh Development Agency and the Welsh Office, it was taken over by a consortium of councils and quangos and turned into a vast commercial and multiplex heritage leisure development (Dicks 2003, p.31).

The project developed into a 'living history' heritage visitor site in a specific political context: the Welsh Development Agency which administered the region was a government agency, it was 'an arm of the Conservative-controlled UK Government' (ibid, p.31), despite the dominance of the Labour Party in Wales. At a time when Devolution was becoming an important question in Britain, the 'project (...) became intensely contested in the local community' (ibid). A few years later, by 1990, the Rhondda Heritage Park had emerged as local heritage museum.

In the 1990s, the industrial identity of Wales was already a thing of the past and the country had developed a large service economy (Dicks 2000). However, the situation in the Rhondda Valley remained difficult for many people, a large number of whom left for Cardiff. Tourism in the industrial valleys, which appeared as an important development asset during the economic depression, remained largely undeveloped in 2000. Tourists made only one-day journeys, and only two sites, among a dozen, were large enough to attract economic development. Another fact must be considered. In a report by the Wales Tourist Board published in $1983,{ }^{7}$ people of the Valley were described as lacking in self-confidence, inward looking, 'obstinately clinging to old ways of thinking' (Dicks 2000, p.30). Initially, the Rhondda Heritage Park had appeared to the Welsh Development Agency as an instrument for the population to gain access to a 'brave new world far removed from labourites coalmining inheritance' (ibid). The tourism heritage option implied that people agreed to become heritage entrepreneurs. This meant that they had to change their ways of thinking, that they had to put aside their proletarian identity and simultaneously preserve the marks of their collective singularity in order to establish the mythical place of the great human and industrial adventure of coalmining: the story told by the Park should be consistent with both the national epopee of the coalmining and the local imagined community that was strongly set in the local labourite political culture, 'built on the ideal of hard graft, the family wage and community spirit' (ibid, p.100). 


\section{Rautenberg}

So the heritage project, as it contributed to preserving landscapes and buildings, aimed to transform the labouring class into a local community with its own rituals, its culture and its narratives. ${ }^{8}$ The people of the place earned a new name: the 'Black Gold' community, which is also the denomination of the project. However, a touristic re-production of identity and place is not easy for people to accept. Visitors are given a view of the community through images that give a very partial portrait if its past and identity. Dicks (2000, p.244) noted, 'To suggest that heritage can grant access to the vernacular hides the fact that the visitors are not experiencing community, but gazing upon it', which is not easy to deal with. We could say, with Bella Dicks, that by making the community an object of spectacle, tourism metamorphoses them from the subjects of the history into objects (ibid).

The Rhondda Heritage Park has succeeded in providing technical knowledge in the form of a visible attraction, a leisure destination for tourists and for the future generations of local residents. However, it has failed from an economic point of view. Local government has regularly had to subsidize the Park. As Dicks's notes, 'Where history attracts entrenched local cultural allegiances, it cannot be detached from the community and deployed "rationally" as a market commodity. Since heritage remains, on the whole, regulated and controlled through public channels of governance, it is necessarily subjected to the dynamics and complexities of the local public sphere' (2003, p.41). Local councils and the public grants system have played an important role in the urban development. Many local variables, such as allegiances, the formation of historical relations and local interests have prevented the application of a single pattern. As Dicks goes on to state, 'Heritage exposes the impossibility of bending social realities to an imagined spirit of free enterprise' (ibid).

\section{Conclusion: A Resource for Public Policies Ignored by the Population}

Between the described two situations, we can apparently find two main differences, and, above all, many similarities. First, the professed aims of the public institutions $\square$ on the one hand, economic development; on the other hand, cultural and social development $\square$ translate into two different public policies. A second difference to be noted concerns the notion of community, which is quite ordinary in United Kingdom but difficult to use in France. In the 1990s, this notion was never used in French public policies, which confused community and what the French call 'communautarisme'. The Welsh Development Agency appeals to the collective imagination to promote the special mentality of the people, forgetting the miners' working-class identity and remembering only the local and cultural identity of the community, the Black Gold Community. In the Culture Commune, the notion of community has never been used to talk about the miners, whether in the past or today. According to the context, one speaks of inhabitants (of a place), of miners, of local society, of population (when speaking in general terms), of Polish, of 'immigrants' (specifically, for immigrants from North-Africa). We apparently observe two heritage regimes defined by different public policies - aimed at economics in one case and at cultural development in the other $\square$ and two different conceptions of the local actors - considered as a community in Wales and as a local population in France. We also have to note that militants seem to be more engaged in the Rhondda project than in the Culture Commune, ${ }^{9}$ and that national frames - ideological and political $\square$ are important in order to define heritage, whatever the struggle with local conceptions, which can be various and antagonistic.

However, as each regime has now been operating for several years, we note how close the two operations are. Heritage opens up wider questions of representations and policies: how culture is intertwined with economy, how the local is implicated in wider spatial and social formations, how the past is produced as a set of stories told in the present and how those stories evoke the past, the present and the future of the 'community' or the local society. Heritage is also part of the new culture of display, 'in which different sites are transformed 
into sights to capitalize on new forms of consumption' (Dicks 2000, p.33). According to these new forms of consumption, heritage must be declinable into vernacular forms which are 'stereotypified' and 'mythfied' (Rautenberg 2010). 'Marketization' or 'culturalization' use fairly similar stereotypes, though apparently opposite ideological frames. We also observe similarities between local policies. In both examples, we noted a common will to transform the industrial heritage rather than destroy it, to express a collective identity in the artefacts of past industrial glory, to make different types of actors work together under the ambiguous protective wing of the State. In both cases, the project began with the mobilisation of local militants and politicians. Public actors have always been more or less involved, according to the phases of the project. They were present in supporting the launch of the project and in organizing the round table for fund raising — public and private - aimed at legitimating the project at EU or state government levels. According to Patrick Le Galès' conclusion, in spite of apparent differences between the British and Continental models, there exists 'a kind of standard European city organized around a mix of public and private, public intervention, development of culture and integration' (2003, p.391). But are populations really involved in those projects?

We saw that the local community (in Britain) or the local society (in France) consider heritage to be a proper part of their identity and that many of their members contest — or do not feel concerned by - public projects, whatever their economic or cultural aims. In both cases, they are seen as external, not fully legitimate. The French miners do not appear to be really involved in the artistic project, ${ }^{11}$ and we have seen that the part of local society which felt most concerned were children from mining families who had acceded to the lower-middle class and people originally from outside the Black Country. ${ }^{11}$ Finally, from a global point of view, we can apply the main paradox of the Rhondda project to the Culture Commune project: development projects aiming to foster the projection of local societies into the future were based on a 'mythification' of labour and of the workers' culture, whose values seem largely inefficient in the modern world. In other words, there is a fundamental incompatibility between local popular representations and entrepreneurial or cultural regeneration, even when the latter is supported by local authorities. In both cases, we observe the re-invention of an 'imagined community' by external actors, despite local collective aspirations, as described by Bella Dicks. Finally, in both cases, this is probably the price to pay for sharing that kind of heritage with a large public.

\section{Notes}

1. We evoke the French André Chastel, who invented the French Inventaire général des monuments et des richesses artistiques de la France at the ministry of Culture in the 1960s, and Pierre Nora, whose conception Memory includes heritage, as noted by François Hartog; and, in Great Britain, the Englishman David Lowenthal and the well-known 'inventor' of Tradition, Eric Hobsbawm.

2. We do not intend to discuss this point in the present article. To summarize, we note that she distinguishes heritage, as basically 'something handed down from one's ancestors or from the past' that you cannot change, from patrimony, as 'something that you are responsible for developing, (...) that you have actively constituted in order to be handed on to future generations' (2010, p.54). For simplicity, we shall keep the word heritage but the issue should not be forgotten.

3. This research was entrusted to the authors by the Direction régionale des affaires culturelles of the ministry of Culture, and by the 'communauté d'agglomération Artoiscomm' which is the main public sponsor of Culture Commune. Artoiscomm includes 34 municipalities of the Bassin minier and is the main promoter of the project to include the region in Unesco's World Heritage Sites (http://www.bmu.fr/en/). The authors have been familiar with the place for 


\section{Rautenberg}

several years and were regularly consulted about the collection of local memories undertaken by the Culture Commune (the report is not available).

4. It should be noted that the same situation exists in the district of Saint-Etienne, the second coal-mining region in France, which we are currently investigating.

5. For several years, the whole area has been preparing its application for the UNESCO list of the world's cultural heritage, and in 2009 the Ministry of Culture proposed to protect almost 70 buildings.

6. Many of the shows were free, as it is customary in the street arts.

7. This is titled, 'Realising the Tourism Potential of the South Wales Valley'.

8. This is to say that French and British social sciences have used differently the word community. For French sociologists and anthropologists the concept is close to the mechanic societies described by Durkheim. It is seldom used to evocate a group of people sharing human communion, culture and a collective feeling to belong to a social-class consolidated by collective action, as it was supposed to be in the Rhondda valleys.

9. Several groups of militants were engaged in other cultural projects, but they did not succeed in gaining the support of the national institutions.

10. The trade unions have established a museum in Lens, but it is not very popular.

11. A wider inquiry, which we have not been able to carry out, would be needed to verify this hypothesis.

\section{References}

Barth, F., 1969. Ethnic Groups and Boundaries: The social organization of culture difference. Bergen/Oslo: Universitetsforlaget. London: George Allen \& Uwin.

Béhar, D. and Estèbe, P., 2009. L'Etat peut-il avoir un projet pour le territoire ? Annales de la recherche urbaine, 82, 80-91.

Cegarra, M., 1999. La mémoire confisquée. Les mineurs marocains dans le nord de la France. Lille: Presses du Septentrion.

Centre historique minier du Nord-Pas-de-Calais, 2004. Tous gueules noires. Histoire de l'immigration dans le bassin minier du Nord-Pas-de-Calais. Lewarde: Centre historique minier du Nord-Pas-de-Calais.

Chaudoir P., 2009. La rue: une fabrique contemporaine de l'imaginaire urbain. Culture et musées, 12, 51-64.

Choay, F., 1992. L’Allégorie du patrimoine. Paris: Seuil.

Debray, R. 1999. Les monuments ou la transmission comme tragédie. In Debray, R., ed. L'abus monumental? Paris: Fayard, 11-32.

Dicks, B., 2000. Heritage, place and community. Cardiff: Un. of Wales.

Dicks, B., 2003. Heritage, Governance and Marketization: a Case-study from Wales, Museum and Society, 1(1), 30-44.

Edensor, T., 2005a. Industrial ruins. Space, Aesthetics and materiality. Oxford. New-York: Berg.

Edensor, T., 2005b. Spaces of Dereliction: Industrial Ruins in the UK [online]. Manchester

Metropolitan University. Environmental and geographical Sciences. Available from :

http://www.sci-eng.mmu.ac.uk/industrial_ruins/default.asp [ Accessed 28 August 2011]

Fabre, D., ed., 2000. Domestiquer l'histoire. Ethnologie des monuments historique. Paris: Editions de la maison des sciences de l'homme.

Glévarec, H. and Saez, J.P., 2002. Le patrimoine saisi par les associations. Paris: La Documentation française.

Graham, B. and Howard, P., 2008. Introduction. In: Graham, B., Howard, P., eds. Heritage and identity. Aldershot: Aschgate, 1-15.

Hartog, F., 2002. Régimes d'historicité. Présentisme et expérience du temps. Paris: Le Seuil. 
Hartog, F., 2005. Time and Heritage, Museum, International, 227, 7-18.

Harvey, D., 1985. The urbanisation of Capital. Oxford: Blackwell.

Harvey, D., 2008. The history of Heritage, in Graham, B., Howard, P., eds, Heritage and identity, Aschgate, 19-36

Koselleck, R., 1990. Le futur passé [The Past Future] (trans. by J. Hoock and M.-C. Hoock). Paris: Editions de l'Ecole des Hautes Etudes en Sciences Sociales.

Lascoumes P. and Le Galès, P., 2005. Gouverner par les instruments. Paris: Presses de Sciences Po.

Le Galès, P., 2003. Le retour des villes européennes. Sociétés urbaines, mondialisation, gouvernement et gouvernance. Paris: Presses de Sciences Po.

Lowenthal, D., 1985. The Past is a Foreign country. Cambridge: Cambridge Un. Press.

Morisset, L. K., 2009. Des régimes d'authenticité. Essais sur la mémoire patrimoniale. Rennes: Presses universitaires de Rennes, Presses de l'université de Québec.

Morisset, L. K. 2010. 'Patrimony, the concept, the object, the memory and the palimpsest. A view from the History of Architecture', JSEAC, 35, 53-62.

Nora, P., 1986. Les lieux de mémoire. La Nation, 3 vol. Paris: Gallimard.

Pinson, G. 2009. Gouverner la ville par projet. Urbanisme et gouvernance des villes européennes. Paris, Presses de Sciences Po.

Poirrier, P., 2010. Politiques et pratiques de la culture. Paris: La Documentation française.

Ponty, J., 1995. Les Polonais du Nord ou la mémoire des corons. Paris: Autrement.

Rabier, J.C., ed., 2002. La Remonte. Le bassin minier du Nord-Pas de Calais, entre passé et avenir. Lille: Presses universitaires du Septentrion.

Rautenberg, M., 2003. La rupture patrimoniale. Grenoble: A la Croisée.

Rautenberg, M. and Trigano, S., 2009. Une institution culturelle et son territoire: Culture commune, scène nationale du bassin minier du Nord-Pas de Calais, ou l'art de 'transfigurer' la mémoire ouvrière. In: Arrieta Urtizberea, I. (ed.), Activaciones patrimoniales e iniciativas museísticas: ¿por quién ?y ¿para qué ?. San Sebastian: Universidad del Pais Vasco, 31-57.

Rautenberg, M., 2010. Stereotypes and emblems in the construction of Social Imagination. In: Kontopodis, M. and Matera, V., Doing Memory, Doing Identity: Politics of the Everyday in Contemporary Global Communities; Outlines. Critical Practice Studies, 2, 126-137.

Samuel, R., 1994. Theatres of Memory. Volume 1: Past and Present in contemporary Culture. London: Verso.

Smith, L., Shackel, P. and Campbell, G., 2011. Introduction: class still matters. In Smith, L., Shackel, P. and Campbell, G., eds., Heritage, Labour and the Working Classes. London and New York, Routledge.

Smith, M., P. and Bender, T., 2001. City and Nation. Rethinking "place and Identity. New Brunswick and London: Transaction publishers.

Tornatore, J.L., ed., 2010. L'invention de la Lorraine industrielle. Quêtes de reconnaissance, politiques de la mémoire. Paris: Riveneuve.

Trigano, S., 2010. Entre figure du mineur et évocation de l'ouvrier contemporain. Mise en scène d'un mort-vivant par la compagnie Hendrick Van der Zee. Théâtre/Public, 196. 